\title{
TRANSITIONAL EPOCHS
}

\section{TRANSNATIONAL FEMINISMS: GENDER AND HISTORICAL KNOWLEDGE IN POST-SOVIET RUSSIA (Part 2)}

\author{
Choi Chatterjee, Karen Petrone \\ California State University, \\ Los Angeles \\ University of Kentucky, Lexington
}

Чой Чаттержи, Карен Петрон

Калифорнийский государственный

университет,

Университет Кентукки, Аексингтон

\begin{abstract}
In this essay, Choi Chatterjee and Karen Petrone examine how feminist and gender theories traveled between Russia and the West after the fall of the Soviet Union by featuring the careers of two eminent scholars: Natalia Pushkareva and Tatiana Barchunova. They chronicle the parallel development of feminism in the Soviet Union and in the English-speaking world, and then discuss the development of gender studies programs and women's activism in Russia after 1991. Using the intellectual biographies of Barchunova and Pushkareva, the authors show Western ideas about feminism meshed with Russian ones in post-Soviet gender and women's studies. While post-Soviet pressures push toward the de-politicization of the field, both Barchunova and Pushkareva maintain a critical edge in their scholarship, supporting and promoting women's activism, raising awareness of Russian women's issues past and present, and advancing feminist theory.
\end{abstract}

Keywords: feminist and gender theories, Russia, transnational feminism, women`s activism.

E-mails: cchatte[at]exchange.calstatela.edu; petrone[at]email.uky.edu

Copyright: (C) 2014 Chatterjee and Petrone. This is an open-access article distributed under the terms of the Creative Commons Attribution License (CC BY 4.0), which permits unrestricted use, distribution, and reproduction in any medium, provided the original authors and source are credited. 


\title{
ТРАНСНАЦИОНААЬНЫЙ ФЕМИНИЗМ: ГЕНДЕР И ИСТОРИЧЕСКОЕ ЗНАНИЕ В ПОСТСОВЕТСКОЙ РОССИИ (Часть 2)
}

\begin{abstract}
Аннотация. В данном эссе Чой Чаттержи и Карен Петрон рассматривают то, как феминистские и гендерные теории "путешествуют" между Россией и Западом после распада Советского Союза на примере карьер двух известных ученых: Наталии Пушкаревой и Татьяны Барчуновой. Авторы характеризуют парамлемьное развитие феминизма в Советском Союзе и англо-говорящем мире, затем анализируют развитие программ гендерных исследований и женский активизм в России после 1991 г. С помощью интемлектуальных биографий Барчуновой и Пушкаревой Чаттержи и Петрон показывают то, как западные идеи о феминизме сплетались с российскими в постсоветских гендерных и женских исследованиях. Хотя постсоветские обстоятельства побуждают к деполитизации этих направлений, и Барчунова, и Пушкарева сохраняют критицизм в исследованиях, поддерживая и продвигая женский активизм, повышая осведомленность о женских проблемах в прошиом и настоящем и развивая феминистскую теорию.
\end{abstract}

Ключевые слова: феминистские и гендерные теории, Россия, транснациональный феминизм, женский активизм.

Tatiana Vladimirovna Barchunova, a faculty member in the Department of Philosophy at Novosibirsk State University, exemplifies the new breed of gender experts on Russian campuses. Her career and persona showcase both the strong continuity of the Soviet intellectual order and the new orientation of post-Soviet intelligentsia. ${ }^{1}$ An accomplished linguist, Barchunova is fluent in English as well as several other European languages. Her command of the feminist theoretical corpus is exemplary, even though she does not find all feminist writings useful. In fact, she feels that Western scholars such as Sheila Fitzpatrick and Nancy Ries, who do not explicitly deal with gender, are more successful in describing the Soviet experience. Barchunova believes that much of the Western analysis of media representations of women and of women and globalization is particularly lacking in insight, and that a superficial use of postmodern discourse prevents complex analyses (Barchunova 2009).

Barchunova partly attributes her feminist orientation to the influence of her mother, a literary critic who in the early 1990s coedited the reprint edition of Feoktist Berezovskii's 1929 novel, Women's Paths. Berezovskii, a

${ }^{1}$ The authors gratefully acknowledge that the information in the following section is culled from personal correspondence with Dr. Barchunova. 
Siberian of Polish descent, wrote this novel at the height of the early Soviet women's movement in the 1920s, but the novel was not reprinted after 1934 (Berezovskii 1993). These circumstances demonstrate the intellectual connections and continuities between the burgeoning feminism of the late Soviet period and early Soviet traditions of women's emancipation that had been inhibited in the Stalin years. Indeed, the transnational feminism of the 1990s had roots in the transnational feminism that had bloomed more than a century earlier.

Barchunova came to Western feminism through a fairly traditional route in Soviet academia. In 1988 she bought a book on gender and science by Evelyn Fox Keller, a mathematical biologist, for 5 rubles and 66 kopecks at a state-subsidized bookstore (Fox Keller 1985). As a graduate student at the Institute of History, Philology, and Philosophy at Novosibirsk State University, she had access to an excellent library. While researching her dissertation on the development of social sciences and models of language, she became interested in the history and philosophy of science. Her university subscribed to various American and English journals on the subject, and her advisor asked her to review the then current discussions in the field. She soon discovered a conversation on "woman's styles of thought" and was intrigued by the concept. Reading further in the subject, Barchunova wrote and presented a paper entitled "Feminism and the Style of Modern Culture" at a 1989 Novosibirsk conference on "The Human Factor and Scientific Progress." Although the paper was not particularly well received by an audience suspicious of feminism in academia, she subsequently coauthored an article on the subject that appeared in an edited volume on philosophy (Antipov 1991).

A survey of Barchunova's curriculum vitae reveals that some Russian academic feminists have wide intellectual interests and play a variety of roles in the formation of postsocialist civil society. Along with their production of specialized research, they are engaged in a series of strategic activities to highlight persistent patterns of gender discrimination in academia in particular, and in society at large. Knowledge of critical theory, especially pertaining to the Western canon, is considered currency of great value and can be parlayed at various venues at the local, national, and international level. Barchunova has written numerous academic essays on the subject of gender, developed courses on gender theory at her university, received many prestigious grants, and traveled abroad to attend conferences and conduct research. At the same time, she has translated numerous Western texts into Russian. These include texts on feminist theories, textbooks at the secondary level, and commentaries on the Bible by Protestant theologians. She has served as a gender consultant for various NGOs as well as state-run organizations at the provincial and municipal level. In 1999 Barchunova started a privately-funded library on gender and women's studies, the Resource Center for Humanitarian Education. The library now contains almost 1500 books and articles on philosophy, sociology, anthropology, history, religion, law, and human rights. Russian feminists have consistently supported the 
proliferation of information beyond the borders of state-controlled sites and have been the most ardent promoters of transnationalism in research and education (Zdravomyslova and Temkina 2007).

Barchunova's scholarly work points to the important fact that transnational feminist scholarship not only has to overcome political obstacles but also logistical ones. In a 2006 article entitled "A Library of Our Own? Feminist Translations from English into Russian," Barchunova assesses the quality of translations of Western gender theory into Russian and in many cases found them to be inadequate (Barchunova 2006). Due to time pressures and some translators' lack of skill, certain aspects of complex gender theory were rendered nearly incomprehensible in the Russian translations. Some mistakes came from mistranslations of idiomatic language that introduced unpredictable (and sometimes comical) meanings into the texts. Other mistranslations appeared to be more deliberate (Barchunova 2006, 140-42). One translation of a major feminist theorist, Nancy Fraser, seemed systematically to omit references to the interrelation of race and gender, thus fundamentally altering the analytical thrust of the text. Thus the transnational conversation among feminists is, in part, predicated on mutable and unstable theoretical bases especially as key Western concepts are radically transformed during the course of their transnational travels. While, of course, all theory is altered as others interpret it (Said 1983, 226-47), the circumstances described by Barchunova suggest the possibility of a particularly wide divergence between what was intended by Western gender theorists and what is understood by Russian scholars and students using translations.

Currently we can discern some points of tension within academic feminist discourse in Russia. There are those who worry that critical theory has been deliberately shorn of its radical activism and analyses of power to suit the political circumstances of post-Soviet Russia, or that it has been cynically and superficially adopted in order to gain access to Western funding (Ushakin 2000, 34-39). Thus Elena Zdravomyslova and Anna Temkina argue that while women's studies was a product of social and political feminist movements in the West, in post-Soviet civil society feminist discourses emerged solely as a means of intellectual critique, without formal links to mass organizations and political groups (Zdravomyslova and Temkina 1999). Barchunova, in a widely cited article, criticizes researchers who prefer to use the term "gender asymmetry" rather than speak openly about gender inequality and discrimination in Russian society (Barchunova 2003). Barchunova also refers to several published works on gender that reduce gender to biological sex and often inadvertently reproduce the gender asymmetry that they purport to critique. She fears that because of the relatively marginal status of gender and women's studies in the Russian academy, some researchers are afraid to challenge each other's work openly, not wanting to jeopardize their fragile epistemological enterprise within academia. According to Barchunova, "the initial impetus of gender theory as a critical theory is undermined by the specific conditions of its emergence in the Russian-speaking world" (Barchunova 2003, 10). 
Barchunova is right in so far as the category of gender is often used by post-Soviet academics to describe the complementary roles of men and women in Russian society that legitimize the traditional gender order, rather than to criticize vastly unequal power relations inherent in the social and political structures, or to analyze the normative discourses that radically condition the explorations of self and subjectivity. The philosopher Olga Voronina has called this approach the "lozhnaia teoriia gendera," or the false theory of gender (Voronina 2001/2002, 57). At the same time, Barchunova's career demonstrates that while intellectuals in the post-Soviet era are currently unable to coordinate large-scale social movements such as those that challenged the gender status quo in the West, nonetheless there is great receptivity within academic circles to the trenchant social commentary emerging from within women's studies. The careers of individuals analyzed in this essay demonstrate that there are some outspoken scholars in contemporary Russia who are committed to fostering open debate and critical discussion, the sine qua non of any oppositional social movement.

While some Russian-speaking scholars worry about the inadequate understanding of Western critical theory and the depoliticization of its radical content, others are concerned about the heedless importation of Western theories. Natalia Pushkareva, pragmatist extraordinaire, believes that the profligate importation of Western theories often leads to simplifications, schematization, and the undue privileging of those scholars who have mastered the Western canon. She is particularly concerned about the growing divide between the haves and the have-nots in the scholarly community, between those who speak "gender" and those who do "old-fashioned" women's history. She feels that these inequalities have been deeply exacerbated by the influx of Western funding to select centers, institutions, and individuals. In the section that follows, we will analyze the career and scholarly works of Natalia Pushkareva from three intertwined and overlapping angles: her position as the preeminent historian of Russian women, her role as a builder of institutions and academic communities, and her self-identity as a nationalist who is committed to expanding the spaces and networks of Russian civil society based on a feminist understanding of the nationalist past.

\section{Post-Soviet Feminism: Scholarship as Nation-Building?}

Natalia Pushkareva is considered to be one of the best-known practitioners of women's history in Russia today, and has an unparalleled familiarity with Russian sources on women's history from the tenth century to the present. She has published prolifically and widely on various aspects of women's history, which, due in part to her untiring efforts, is now a recognized subject in history departments in Russia. History as a discipline in both the Soviet Union and post-Soviet Russia has been notoriously indifferent to documenting the activities, experiences, and voices of women, as even a cursory examination of eminent Russian journals such as Otechestvennaia istoriia and Voprosy istorii reveals (Repina 2006). An advocate of Rankean empiricism, Pushkareva bases her analysis on prodigious research and the 
patient collection, collation, and analysis of historical sources. Her history of Russian women in Kievan Rus ' has been issued in numerous editions, and more recently she has published widely on various aspects of private life in Russian history. ${ }^{2}$ In 1999 , based on research published previously in two seminal texts, she wrote a monograph intended for western audiences entitled Women in Russian History: From the Tenth Century to the Present (Pushkareva 1997a; 1989; 1996). This book, a product of international collaboration, was edited and translated by Eve Levin, a senior American scholar who specializes in the history of gender and sexuality in premodern Russia and the Balkans. Pushkareva and Levin met when they were both graduate students working under the supervision of academician Valentin Lavrentievich Ianin. Their scholarly friendship blossomed when they both "realized that [they] had somehow reached similar conclusions concerning the status of women in medieval Russia" (Idem 1997a, xiv). In their unusual collaboration, Levin and Pushkareva together challenge dominant historiographies and cross Cold War boundaries (Levin 2003).

Pushkareva's unique text is a tour de force with few comparable works in Russian or any other language. Based on her rich compilation of historical, literary, ethnographic, and archaeological evidence, the scholar, in a series of chronological chapters, painstakingly builds her central argument that, contrary to the received wisdom about the oppression and seclusion of Russian women, women have always been an integral part of Russian history and have played vital roles in politics, society, and culture. She paints vivid pictures of a gallery of powerful and politically astute female rulers who worked untiringly to strengthen the lineages of the state in Kievan Rus'. At the same time, she does not neglect the everyday life of women from the lower classes. She includes interesting ethnographic materials pertaining to daily life practices, as well as information on legislation about the regulation of sexuality and family, and the adjudication of property. Moreover, through a careful analysis of voluminous data on land deeds and charters, she proves conclusively that women owned and could dispose of property during this early period. The book is deeply polemical in both intent and content in so far as it argues against a corpus of earlier Western and Russian historical accounts that have represented medieval and early modern Russian women as unseen, unheard, and subject to overwhelming patriarchal subordination, domination, and often outright seclusion ${ }^{3}$.

In subsequent parts of the book, Pushkareva examines the roles of women in later periods of Russian history from Muscovy to the onset of the Bolshevik revolution. The section on the nineteenth century is particularly interesting because she substantially rewrites Soviet historiography that

\footnotetext{
2 Pushkareva 1997b; 2002a. In her histories of private life and sexuality, Pushkareva also highlights the theme of women's independence and range of choices.

${ }^{3}$ Pushkareva most clearly formulates her critiques of various historiographical traditions in her 1989 work, Zhenshchiny drevnei Rusi (Pushkareva 1989, 177-211).
} 
had only narrated the activities of revolutionary women such as Vera Figner and Alexandra Kollontai, and had relegated the feminist efforts of women from higher social classes to the "dustbin of history." Using ideologically reverse tactics, she condenses the contribution of revolutionary women to a few pages, and instead elaborates on the activities of salon hostesses, women writers, philanthropists, and advocates of access to higher education and equal rights in the long nineteenth century. In a subsequent article, she reexamines the roles of these women from the standpoint of the new and favorable perceptions of the history of the prerevolutionary period in postSoviet Russia today (Pushkareva 2002b). In an inclusive vision of the Russian nation, she argues that, unlike Western feminists who pursued a woman-centered agenda exclusively, nineteenth-century Russian feminists were interested in furthering the rights of both men and women as well as those of the lower orders of society. Moreover, unlike Western philanthropists who trained women of the lower classes to be good wives and mothers, Russian feminists wanted to make women economically independent, and in order to accomplish this, they set up communitarian work artels. ${ }^{4}$ These practices were consonant with the long-inherited traditions that had created Russian women's rights to both movable and immovable property.

While the activities of some of these early Russian feminists have been documented by Western historians, one must remember that for the broad Russian reading public, stories about nineteenth-century women writers, equal rights advocates, professionals, and philanthropists are essentially new. ${ }^{5}$ Pushkareva's publications form the foundations for a woman-centered narrative of a Russian past that is peopled by wise and pragmatic women. This kind of scholarship is especially important as very few history textbooks in Russia at both the secondary and undergraduate level either mention women or analyze their achievements. The capacity for self-sacrifice, spiritual strength in the face of great adversity, and constructive community-building efforts of Russian feminists in the nineteenth century in many ways parallel the efforts of women's organizations in contemporary Russia. By unearthing the activities of these nineteenth-century women, she also uncovers the lost history of pragmatic reformism and constructive nationbuilding in the Russian past. If history in the modern age has been one of the primary tools of nationalism in both capitalist and socialist societies, then Pushkareva is one of its ablest practitioners. By foregrounding the activities of these particular women who achieved their ends through patient collaboration and compromise rather than radicalism, she is also smuggling in her covert feminist agenda of creating a genealogy of women's activism,

\footnotetext{
${ }^{4}$ However, as both Barbara Engel and Richard Stites have shown, these community enterprises, contrary to literary representations in Chernyshevsky's novel, What is to be Done, were often unable to survive the initial enthusiasm of their founders. See citation below.

5 Stites 1978; Edmondson 1984; Johanson 1987; Goscilo and Holmgren 1996; Lindenmeyr 1996; Ruane 1994. See also I. I. Iukina's excellent volume, Russkii feminism kak vyzov sovremennosti (Iukina 2007).
} 
different from the discredited versions of Soviet revolutionary feminism. By creating an alternative cast of heroines to supplant the revolutionary pantheon, she offers narrative therapy and textual succor to Russians recovering from the multiple traumas and deep wounds inflicted by a century of war, revolution, and forced modernization. As she writes in the epilogue to her text, "Women's active role in society and business, which has developed so markedly in our time, has its roots in the distant past. Contemporary women have the opportunity to draw inspiration from their history and traditions, and with good sense and strength of will, they will forever endure" (Pushkareva 1997a, 266). Pushkareva hopes to infuse both a woman-centered as well as a feminist subtext into the Russian search for a "usable past."

Similar to her nineteenth-century feminist precursors, Pushkareva has combined extensive scholarship with exemplary academic activism and community outreach in her public career as a historian. ${ }^{6}$ She is the founding member of the prestigious Moscow Center for Gender Studies, established at the Institute for Population Studies in Moscow in 1989 before the collapse of the Soviet Union. With the assistance of Western funding, the Center has organized important conferences of scholars and activists from Russia, Ukraine, and the West. The Center has also convened summer schools for scholars, university teachers, and graduate students from across the country in order to acquaint them with research and theories in the fields of women's and gender studies. These summer schools have made it possible for scholars and students to forge links at the national level and engage in collaborative research projects (Khotkina 2002). She also has been a consistent advocate of an intellectual equivalent of the nineteenth-century Populist crusade of "Going to the People." She is concerned about the lack of publication of historical monographs and feels that edited volumes and historiographical essays have to be supplemented by serious research in women's history. She believes that the best way to increase the production of serious historical research in women's issues is by increasing intellectual contacts among historians at various universities, especially in the provinces, through conferences and summer schools. Reversing the Soviet institutional hierarchy that continually privileged the center over the provinces, she on several occasions has asserted that the best work in women's history is being done at provincial universities (Pushkareva 1998). She also advocates that her colleagues write clearly and simply so that traditional historians working with older methodologies can understand the new disciplinary impetus emerging from gender studies (Idem 2006).

\footnotetext{
${ }^{6}$ Pushkareva is also the founding member and president of the recently formed interregional organization, Russian Association for Researchers in Women's History (RАИЖИ), whose aims and goals are somewhat similar to the Association for Women in Slavic Studies (AWSS). RАИЖИ has sponsored conferences on women's studies at provincial universities in Yaroslavl' and Tver' among others in order to reach out to local activists and scholars.
} 


\section{Conclusion: The Nation within Transnational Feminism}

In the late nineteenth and early twentieth centuries, the Russian feminist movement was subsumed by two strong political currents: the Social Democratic movement that was overtly critical of what it deemed to be bourgeois feminist efforts, and the Populist and Socialist-Revolutionary movements that used women in a variety of ways within their radical circles, but did not articulate an explicitly feminist agenda. Despite the efforts of dedicated but covert feminists such as Aleksandra Kollontai and Inessa Armand, the feminist movement suffered somewhat of a setback with the victory of the Bolsheviks in 1917. Although women received numerous benefits under the socialist regime, they were constructed as recipients, beneficiaries, active carriers of revolutionary ideology, and exemplary symbols of the modernity of the regime. To a large extent, the Soviet government continued the nineteenth-century exhortations of self-sacrifice, self-abnegation, and dissolution of the self in the larger community. Women continued to be objects representing "terrible perfection," metaphors for social renewal, and sites of contested state discourses. At the same time, as the current generation of gender experts in post-Soviet Russia demonstrates, Soviet ideology did have the potential to empower women, and, more importantly, various Soviet practices engendered powerful notions of feminist subjectivity, agency, and selfhood.

Today Pushkareva warns that the proliferation of various theories and definitions of gender threatens to subsume Russian women's history. According to her, there are those who use the term gender hoping that its neutral connotations will allay fears and suspicions that feminism continues to raise among university administrations and the broader Russian public. ${ }^{7}$ Then there are others who do "women's history," often a code for those who have a hidden feminist agenda. Given the fetishization of critical theory within elite academic circles in the CIS, these practitioners of "women's history" are often considered to be backward. However, as Pushkareva has noted on numerous occasions, it is impossible to do gender without women's history, as both are deeply feminist enterprises (Pushkareva 2001). It is important to remember that without the establishment of the category of women's subjectivity, the construction of the history of female selfhood, and the institutional success of feminist movements, the deep insights that the application of the deconstructionist theories of gender have yielded would not have been possible. Ultimately the broader intent of gender theory and most of its advocates is to enlarge the sphere of feminist politics, mainstream the findings from women's history into public memory and consciousness, and construct a new, more inclusive epistemology.

Motivated by a desire to facilitate a familiarity with critical theory among other Russian scholars, Pushkareva recently published a concise

\footnotetext{
7 See Irina Korovushkina's fine essay on the subject, "Paradox of Gender: Writing History in Post-Communist Russia 1987-1998" (Korovushkina 1999).
} 
and clearly written introduction to some of the major philosophical approaches to gender in various disciplines such as sociology, ethnography, and history (Idem 2007). Reading through her elegant exposition, one is struck by not only her mastery of the Western canon, but also by the fact that the "canon" with its inclusions and exclusions is often constructed from outside by reading audiences. While no text can hope to be entirely comprehensive, it is noteworthy that she has chosen to ignore the critical theories pertaining to race, ethnicity, postcolonialism, transnationalism, and their imbrication in the elaboration of gender regimes. ${ }^{8}$ Despite the considerable differences between the conditions of post-Soviet Russia and those of other developing countries such as India, there are certain similarities with respect to the creation and consumption of historical knowledge in both postSoviet and postcolonial societies (Chari and Verdery 2009; Rogers 2010; Oushakine 2002). In both cases historical texts have to speak to two separate audiences: the sensibilities of a national elite whose fortunes are closely tied to the legitimacy of the nation-state, as well as the intellectual criteria of a transnational intelligentsia, often located in the West. Scholars are often torn between satisfying the demands of the Western academy and Western donors, and mediating the demands of their home institutions and those generated by national political establishments.

In contemporary Russia history is a highly politicized subject and despite intermittent liberalization in the political climate, it still requires considerable personal bravery to practice history as social and political critique. The material rewards of the historical profession in Russia are considerably less than those enjoyed by scholars in the West, and one often runs the risks of incurring serious repercussions because of one's political views. In addition to the significant material and political limitations, historians also have to deal with ideological constraints that make it difficult to articulate ideas critical of the nation, or even to voice transnational sensibilities.

Serguei Oushakine has characterized the widespread resurgence of nationalist and Russo-centric sentiments in contemporary Russia as the "patriotism of despair," and has analyzed the creation of ethnic identity over the course of the last two decades. Rather than dismiss Russian preoccupations with nationalism and ethnic self-identity as incipient fascism or further evidence of unreflective ethnocentrism, Oushakine argues that the emphases on ethnos as a source of primal identity have to be read as symbolic strategies in the face of widespread trauma engendered by the collapse of the Soviet Union (Oushakine 2009; Chatterjee 1993). The exhaustion of leftist ideology as a definitive source of meaning has created a certain suspicion toward internationalism or transnationalism, even though the Putin administration looks to the ideology of Eurasianism as a potent instrument in its

8 Bhaba 1994; Pratt 1992; Said 1978; Chakrabarty 2000; White 1978; Mbembe 2001; Ashcroft et al. 2005. 
foreign policy. Feminist scholars in Russia have to work within this ideological force field where the nation is represented as a suffering woman, redemption is viewed through discourses of fertile motherhood, and national betrayal is personified in the figure of the transnational prostitute (Borenstein 2008). Pushkareva has successfully managed to insert a feminist dimension into Russian visions of civil society by creating an unforgettable version of the national past replete with strong heroines who participated in a range of cultural, social, and political activities that enlarged both the public sphere and civil society. Her feminist and woman-centered historiography also works as a powerful antidote to contemporary trends in Russian popular culture that either glamorize the sexual objectification of women, or call for the relegation of women to domesticity and reproduction in an attempt to recuperate both the traumatized nation and endangered masculinity.

This exploratory essay, the first in a series stemming from our ongoing research on the development of gender studies as a discipline in the postsocialist context, has raised two important issues. First, how do imported theories inadvertently create academic hierarchies, and how has this knowledge transfer affected different forms of gender scholarship in the post-Soviet academy? Second and most importantly, how do we negotiate the demands of the nation as well as the norms and expectations of the transnational scholarly community? As we have argued in this essay, Western knowledge and funding have fostered the proliferation of gender studies but constrained the larger application of feminist knowledge in Russian academic and political circles. At the same time it should be noted that scholars in the West are also struggling to unsettle the privileged status of the nation-state as the primary site of historical knowledge and teaching, and they are searching for global connections and authentic interdependencies that dig deeper than facile comparisons between the reified "East" and the "West." The field of transnational history is in its infancy, and often it is the serendipity of shared imperial pasts that help in the creation of transnational alliances in the twentieth and twenty-first centuries, as is evident by the intellectual traffic between Anglophone scholars in Asia, England, and the US. Similarly Russians scholars are successfully collaborating with centers for gender studies in Lithuania, Ukraine, Finland, and Kazakhstan, a legacy of both the Soviet empire and Marxist feminist internationalism. Collaborations with colleagues in Eastern and Western Europe and in North America have also been a notable development, and joint research ventures that include dual language publications such as Tractus Aevorum continue to increase at a rapid rate in the twenty-first century. ${ }^{9}$ These interactions be-

\footnotetext{
9 See, for example, a recent collaborative project funded by the Institute of Advanced Studies in Paris to look at witchcraft and popular religious practices in early modern Poland, Ukraine, and Russia, entitled "The Center and Periphery in the Religious History of Eastern Europe at the Dawn of Modern Times." The scholars in this project include Elena Smilianskaia (Russian State
} 
tween "the East" and "the West" as real or imagined categories are complex both in terms of power relationships and the formation of scholarly and national identities. We hope that this essay will stimulate further transnational dialogue and self-reflexivity among the participants.

\section{REFERENCES}

1. Antipov, G. A., ed. 1991. Vechnye filosofskie problemy: sbornik nauchnykh trudov [Perpetual Problems of Philosophy: A Collection of Essays]. Novosibirsk: Nauka publ., Sibirskoe otd-nie.

2. Ashcroft, Bill, Gareth Griffiths and Helen Tiffin, eds. 2005. The PostColonial Studies Reader, 2nd ed. New York: Routledge.

3. Barchunova, Tatiana. 2009. Response to authors' survey on the development of gender studies in Russia, February 2.

4. Barchunova, Tatiana. 2006. "A Library of our Own? Feminist Translations From English in Russian." In A Canon of Our Own? Kanonkritik und Kanonbildung in den Gender Studies, edited by Marlen Bidwell-Steiner and Karin S. Wozonig, 133-147. Innsbruck: StudienVerlag.

5. Barchunova, T. V. 2003. "The Selfish Gender, or the Reproduction of Gender Asymmetry in Gender Studies." Studies in East European Thought 55: 3-25.

6. Berezovskii, Feoktist. 1993. Bab'i tropy: roman [Women's Paths: a Novel]. Novosibirsk: Novosibirskoe knizhnoe izd-vo.

7. Bhaba, Homi. 1994. The Location of Culture. London: Routledge.

8. Borenstein, Eliot. 2008. Overkill: Sex and Violence in Contemporary Russian Popular Culture. Ithaca: Cornell University Press.

9. Chakrabarty, Dipesh. 2000. Provincializing Europe: Postcolonial Thought and Historical Difference. Princeton: Princeton University Press.

10.Chari, Sharad, and Catherine Verdery. 2009. "Thinking Between the Posts: Postcolonialism, Postsocialism, and Ethnography after the Cold War." Comparative Studies in Society and History 51 (1): 6-39.

11.Chatterjee, Partha. 1993. The Nation and its Fragments: Colonial and Postcolonial Histories. Princeton: Princeton University Press.

12.Edmondson, Linda Harriet. 1984. Feminism in Russia, 1900-1917. Stanford: Stanford University Press.

13.Fox Keller, Evelyn. 1985. Reflections on Gender and Science. New Haven: Yale University Press.

14.Goscilo, Helena, and Beth Holmgren, eds. 1996. Russia. Women. Culture. Bloomington: Indiana University Press.

15.Iukina, I. I. 2007. Russkii feminism kak vyzov sovremennosti [Russian Feminism as a Contemporary Challenge]. St. Peterburg: Aleteiia.

16.Johanson, Christine. 1987. Women's Struggle for Higher Education in Russia, 1855-1900. Kingston: McGill-Queen's University Press.

Humanities University, Moscow); Katerina Dysa (Mohyla Academy, Ukraine); Urszula Ciernak (Jan Dlugosz University, Poland); Aleksandr Lavrov (University of Paris VIII - Saint Denis); Valerie A. Kivelson (University of Michigan); and Christine D. Worobec (Northern Illinois University). We thank Christine D. Worobec for information on this project. 
17.Khotkina, Zoia. 2002. "Ten Years of Gender Studies in Russia." Russian Social Science Review 43 (4): 4-12.

18.Lindenmeyr, Adele. 1996. Poverty is Not a Vice: Charity, Society, and the State in Imperial Russia. Princeton: Princeton University Press.

19.Korovushkina, Irina. 1999. "Paradox of Gender: Writing History in PostCommunist Russia 1987-1998." Gender and History 11 (3): 569-82.

20.Mbembe, Achille. 2001. On the Postcolony. Berkeley: University of California Press.

21.Rogers, Douglas. 2010. "Postsocialisms Unbound: Connections, Critiques, Comparisons.” Slavic Review 69 (1): 1-15.

22. Oushakine, Serguei. 2009. The Patriotism of Despair: Nation, War, and Loss in Russia. Ithaca: Cornell University Press.

23.Oushakine, Serguei. 2002. O muzhe(N)stvennosti: sbornik statei [About the Manhood: a Collection of Essays]. Moscow: Novoe literaturnoe obozrenie.

24.[Oushakin] Ushakin, S. A. 2000. “'Gender' (Haprokat): poleznaia kategoriia dlia nauchnoi kar'ery? ['Gender' (For Hire): A Useful Category for Research Career?” In Gendernaia istoriia: pro et contra, edited by M. G. Murav'eva, 34-39. St. Peterburg: Nestor.

25.Pratt, Mary Louise. Imperial Eyes. Travel Writing and Transculturation. London: Routledge.

26.Pushkareva, Natalia. 2007. Gendernaia teoriia $i$ istoricheskoe znanie [Gender Theory and Historical Knowledge]. St. Petersburg: Aleteiia.

27.Pushkareva, Natalia. 2006. "Gendernye issledovaniia v istorii i etnologii: poka tol'ko 'voobrazhaemoe'? [Gender Studies in History and Ethnology: Still only 'Imagined'?]" Gendernye issledovanniia 15: 165-73. Accessed on June 25, 2008. www.gender.univer.kharkov/ua/gurnal/15.

28.Pushkareva, N. L. 2002a. "A se grekhi zlye, smertnye...": Russkaia seksual'naia i eroticheskaia kul'tura X-XVII vekov ["These are Sins, Deadly and Unforgivable...:" The Russian Sexual and Erotic Culture from the 10 th to $17^{\text {th }}$ Centuries]. Moscow: Ladomir.

29.Pushkareva, N. L. 2002b. “Derzkie i bespokoiinye' (zhenskaia istoriia Rossii 1801-1905 gg.: formy sotsial'noi aktivnosti) ['Bold and Restless' (Women`s History of Russia from 1801 to 1905: the Forms of Social Activity)]" Otechestvennaia istoriia 6 (6): 52-65.

30.Pushkareva, N. L. 2001. "Istoriia, itogi i perspektivy institutsializatsii women's and gender studies $\mathrm{v}$ rossiiskoi istoricheskoi nauke [The History, Results and Perspectives of the Institutionalization of Women's and Gender Studies in the Russian Historical Science]." Gendernaia istoriia, 21-30.

31.Pushkareva, N. L. 1998. "Gendernye issledovaniia: rozhdenie, stanovlenie, metody i perspektivy [Gender Studies: Origins, Development, Methods and Perspectives]." Voprosy istorii 6: 76-86.

32.Pushkareva, N. L. 1997a. Women in Russian History: From the Tenth to the Twentieth Century, trans. and ed. by Eve Levin. Armonk: M. E. Sharpe.

33.Pushkareva, N. L. 1997b. Chastnaia zhizn' russkoi zhenshchiny: Nevesta, zhena, liubounitsa (X-nachalo XIX vv) [The Private Life of a Russian Woman: Bride, Wife, Lover (From the 10 th to the Early 19th cent.). Moscow: Ladomir.

34.Pushkareva, N. L. 1996. Zhenshchiny Rossii i Evropy na poroge novogo vremeni [Women in Russia and Europe at the Turn of the Modern Age]. Moscow: Institut etnologii i antropologii RAN.

35.Pushkareva, N. L. 1989. Zhenshchiny drevnei Rusi [Women of the Ancient Rus '. Moscow: Mysl'. 
36.Levin, Eve. 2003. "Friends and Colleagues." In Adventures in Russian Historical Research: Reminiscences of American Scholars from the Cold War to the Present, edited by Samuel H. Baron and Cathy A. Frierson, 177-89. Armonk: M. E. Sharpe.

37.Repina, Lorina. 2006. "Gender Studies in Russian Historiography in the Nineteen-nineties and Early Twenty-first Century." Historical Research 79 (204): 270-86.

38.Ruane, Christine. 1994. Gender, Class, and the Professionalization of Russian City Teachers, 1860-1914. Pittsburgh: University of Pittsburgh Press.

39.Said, Edward W. 1978. Orientalism. New York: Pantheon Books.

40.Stites, Richard. 1978. The Women's Liberation Movement in Russia: Feminism, Nihilism and Bolshevism, 1860-1930 Princeton: Princeton University Press.

41.Voronina, Olga. 2001/2002. "Socio-Cultural Determinants of the Development of Gender Theory in Russia and the West." Russian Studies in History 40 (3): 52-69.

42.White, Hayden. 1978. Tropics of Discourse. Essays in Cultural Criticism. Baltimore: Johns Hopkins University Press.

43.Zdravomyslova, Elena, and Anna Temkina. 2007. "Avtonomizatsiia gendernykh issledovanie $\mathrm{v}$ transnatsional'nom prostranstve: feministkie praktiki [The Autonomization of the Gender Studies in Transnational Space: the Feminist Practices]." Gendernye issledovaniia 15. Accessed on June 25, 2008. www.gender.univer.kharkov.ua/jurnal/15.

44.Said, Edward W. 1983. "Traveling Theory." In Idem. The World, the Text, and the Critic, 226-47. Cambridge, Mass.: Harvard University Press.

45.Zdravomyslova, E. A., and A. A. Temkina. 1999. "Issledovaniia zhenschin i gendernye issledovaniia na Zapade i v Rossii [The Women`s Studies in the West and in Russia]." Obschestvennye nauki i sovremennost' 6: 177-185. 